\title{
8-Hydroxy-2'-Deoxyguanosine and Reactive Oxygen Species as Biomarkers of Oxidative Stress in Mental Illnesses: A Meta-Analysis
}

\author{
Xue Xin Goh', Pek Yee Tang ${ }^{2}$, and Shiau Foon Tee ${ }^{1 凶}$ \\ ${ }^{1}$ Department of Chemical Engineering, Lee Kong Chian Faculty of Engineering and Science, Universiti Tunku Abdul Rahman, Kajang, Malaysia \\ ${ }^{2}$ Department of Mechatronics and Biomedical Engineering, Lee Kong Chian Faculty of Engineering and Science, Universiti Tunku Abdul Rahman, \\ Kajang, Malaysia
}

\begin{abstract}
Objective Mental illnesses may be caused by genetic and environmental factors. Recent studies reported that mental illnesses were accompanied by higher oxidative stress level. However, the results were inconsistent. Thus, present meta-analysis aimed to analyse the association between oxidative DNA damage indicated by 8-hydroxy-2'-deoxyguanosine (8-OHdG) or 8-oxo-7,8-dihydro-2'-deoxyguanosine (8-oxodG), which has been widely used as biomarker of oxidative stress, and mental illnesses, including schizophrenia, bipolar disorder and depression. As oxidative DNA damage is caused by reactive oxygen species (ROS), systematic review and meta-analysis were also conducted to analyse the relationship between ROS and these three mental illnesses.

Methods Studies from 1964 to 2020 (for oxidative DNA damage) and from 1907 to 2021 (for ROS) in Pubmed and Scopus databases were selected and analysed using Comprehensive Meta-Analysis version 2 respectively. Data were subjected to meta-analysis for examining the effect sizes of the results. Publication bias assessments, heterogeneity assessments and subgroup analyses based on biological specimens, patient status, illness duration and medication history were also conducted.

Results This meta-analysis revealed that oxidative DNA damage was significantly higher in patients with schizophrenia and bipolar disorder based on random-effects models whereas in depressed patients, the level was not significant. Since heterogeneity was present, results based on random-effects model was preferred. Our results also showed that oxidative DNA damage level was significantly higher in lymphocyte and urine of patients with schizophrenia and bipolar disorder respectively. Besides, larger effect size was observed in inpatients and those with longer illness duration and medication history. Significant higher ROS was also observed in schizophrenic patients but not in depressive patients.

Conclusion The present meta-analysis found that oxidative DNA damage was significantly higher in schizophrenia and bipolar disorder but not in depression. The significant association between deoxyguanosines and mental illnesses suggested the possibility of using 8-OHdG or 8-oxodG as biomarker in measurement of oxidative DNA damage and oxidative stress. Higher ROS level indicated the involvement of oxidative stress in schizophrenia. The information from this study may provide better understanding on pathophysiology of mental illnesses.

Psychiatry Investig 2021;18(7):603-618
\end{abstract}

Key Words Mental illness, Schizophrenia, Bipolar disorder, Depression, DNA damage, Meta-analysis, 8-OHdG.

\section{INTRODUCTION}

Mental illnesses have been affecting 970 million of people all over the world in recent decades. ${ }^{1}$ The prevalence (point estimate per 100,000) of severe mental illnesses such as schizophrenia, bipolar disorder and depression is 282, 594, and 3,627

Received: November 30, 2020 Revised: March 24, 2021 Accepted: May 6, 2021

$\triangle$ Correspondence: Shiau Foon Tee, $\mathrm{PhD}$

Department of Chemical Engineering, Lee Kong Chian Faculty of Engineering and Science, Universiti Tunku Abdul Rahman, Bandar Sungai Long, Cheras 43000 Kajang, Malaysia

Tel: +603-9086 0288, Fax: +603-9019 8868, E-mail: teesf@utar.edu.my

(a) This is an Open Access article distributed under the terms of the Creative Commons Attribution Non-Commercial License (https://creativecommons.org/licenses/bync/4.0) which permits unrestricted non-commercial use, distribution, and reproduction in any medium, provided the original work is properly cited. respectively. ${ }^{2}$ These disorders had been also listed as main contributors of burden of disability with the percentage of $2.8 \%$ in schizophrenia, $2.4 \%$ in bipolar disorder and $11.8 \%$ in depression. ${ }^{3}$ However, the underlying pathophysiology of these mental illnesses remains unknown. Lately, rising evidence postulate the involvement of oxidative stress in developing mental illnesses as brain is vulnerable to oxidative stress due to its structures (i.e., rich with lipid) and functions (i.e., high consumption of oxygen, moderate antioxidant system, presence of reducing agents such as iron and copper, and presence of neurotransmitters with reduced capacity). ${ }^{4-6}$

Oxidative stress occurs when there is imbalance between oxidative and antioxidative systems, leading to the damage to cells, lipids, deoxyribonucleic acids (DNAs) or other compo- 
nents. ${ }^{7.8}$ This imbalance occurs when reactive oxygen species (ROS) such as superoxide radical, hydroxyl radical, and hydrogen peroxide $\left(\mathrm{H}_{2} \mathrm{O}_{2}\right)$ are overproduced. Due to shorter lifespan and higher reactivity, the direct measurement of ROS may not be accurate. Thus, indirect measurement of oxidative stress using parameter of oxidative damage becomes the substitution. ${ }^{9}$

Oxidative DNA damage which is one of the consequences of oxidative stress usually occurs on guanine nucleobase as it is easier to be oxidised compared to others. ${ }^{10}$ The excess ROS will hydroxylate guanine bases and form 8-hydroxyguanine $(8-\mathrm{OH}-$ Gua), producing 8-hydroxy-2'-deoxyguanosine (8-OHdG) through electron abstraction or 8-oxo-7,8-dihydro-2'-deoxyguanosine (8-oxodG) via keto-enol tautomerism of 8-OHdG. However, the terms of 8-OHdG and 8-oxodG are usually used as the same compound in most of the literatures. This production results in oxidative DNA damage, one of the main forms of DNA damage leading to DNA modification with altered functions. ${ }^{11,12}$ Since these mutagenic deoxyguanosines can cross the cell membrane easily, they are more often referred as the indicator of oxidative damage ${ }^{13}$ and further classified as a biomarker in early detection of various diseases. ${ }^{14}$

Weakened antioxidative defence system including decreased antioxidants and antioxidant enhancing enzymes is involved in mental illnesses. ${ }^{15}$ Besides, the association between higher level of oxidative stress markers with mental illnesses further suggests the involvement of oxidative stress in pathophysiology of mental illnesses. ${ }^{8,16,17}$ Increased oxidants and decreased antioxidants have been reported in brain and peripheral tissues of patients. ${ }^{15}$ Oxidative damage has been strongly associated with mental illnesses. Both genetic and environmental factors may cause defects in DNA repair system, thus causing the accumulation of DNA damage which will further lead to changes in neuronal structures and functions. ${ }^{11}$ This relationship was also reported by Christensen et al., ${ }^{18}$ in which 8-oxodG level was significantly higher in urine and cerebrospinal fluid of deceased patients with severe mental illnesses, thus indicating oxidative DNA damage was the major oxidative damage.

There are now several studies published that address oxidative DNA damage in patients with mental illnesses using various samples. Due to different methodological approaches and perspectives, these studies come to inconsistent conclusions. Hence, this present meta-analysis study aimed to analyse the association between oxidative DNA damage indicated by 8-OHdG or 8-oxodG level in patients with mental illnesses, particularly schizophrenia, bipolar disorder and depression. Furthermore, as oxidative DNA damage is caused by excess ROS, we also aimed to systematically review and analyse the association between ROS and each mental illness for further evidence of oxidative stress in each mental illness.

\section{METHODS}

\section{Study search and selection}

Databases of PubMed and Scopus were used to search for studies. For meta-analysis of oxidative DNA damage, studies published between 1964 and August 2020 were selected, using keywords of ("8-hydroxy-2'-deoxyguanosine" OR " 8 -OHdG" OR "oxidative damage" OR "DNA damage") AND ("major mental illness" OR "schizophrenia" OR "bipolar disorder" OR "depression" OR "depressive disorder"). Meanwhile for systematic review and meta-analysis of ROS, keywords of ("reactive oxygen species" OR "ROS" OR "hydrogen peroxide" OR "superoxide radical" OR "hydroxyl radical") AND ("major mental illness" OR "schizophrenia" OR "bipolar disorder" OR "depression" OR "depressive disorder") were used to search for studies published between 1907 and March 2021. Articles of non-English language, non-human subjects such as in vitro or animal studies, and non-research such as review, meta-analysis, overview, book, chapter, editorial or letter were excluded using filter option of database. The studies met the following inclusion criteria were selected: 1) articles were published in peer-reviewed journal, 2) diagnostic methods were reported, 3) both cohort and healthy subjects were included, 4) level of 8-OHdG or 8-oxodG or ROS in living subjects was presented, and 5) enough data to calculate effect size were provided (for meta-analysis only). The flow diagrams of study selection for oxidative DNA damage and ROS are shown in Figures 1 and 2 respectively.

\section{Data extraction and analysis}

First author's name, publication year, demographic characteristics (age and gender), diagnostic method, disease type, patient status, illness duration, medication and specimen were extracted from each study. The mean and standard deviation or other data forms of 8-OHdG or 8-oxodG and ROS levels were extracted to calculate each effect size respectively. The characteristics of studies included in analysis of oxidative DNA damage and ROS are shown in Tables 1 and 2 respectively.

Comparison of 8-OHdG or 8-oxodG and ROS levels between patients with mental illnesses (schizophrenia, bipolar disorder and depression respectively) and healthy controls were analysed in present study using Comprehensive Meta-Analysis (CMA) version 2 (Biostat, Englewood, NJ, USA). Effect sizes (Hedges' g) and 95\% confidence intervals were pooled using fixedeffect and random-effects models. A random-effects model was preferred when high heterogeneity was present, ${ }^{19}$ whereas a fixed-effect model was preferred for analysing small number of studies..$^{20} \mathrm{~A}$ p-value of less than $0.05(\mathrm{p}<0.05)$ was considered significant. The heterogeneity was tested using $\mathrm{Q}$ statistic value and I-squared $\left(\mathrm{I}^{2}\right)$, in which $\mathrm{I}^{2} \leq 25 \%, 25 \%<\mathrm{I}^{2} \leq 50 \%$ and high $\mathrm{I}^{2}>50 \%$ indicating low, moderate and high heterogeneity 


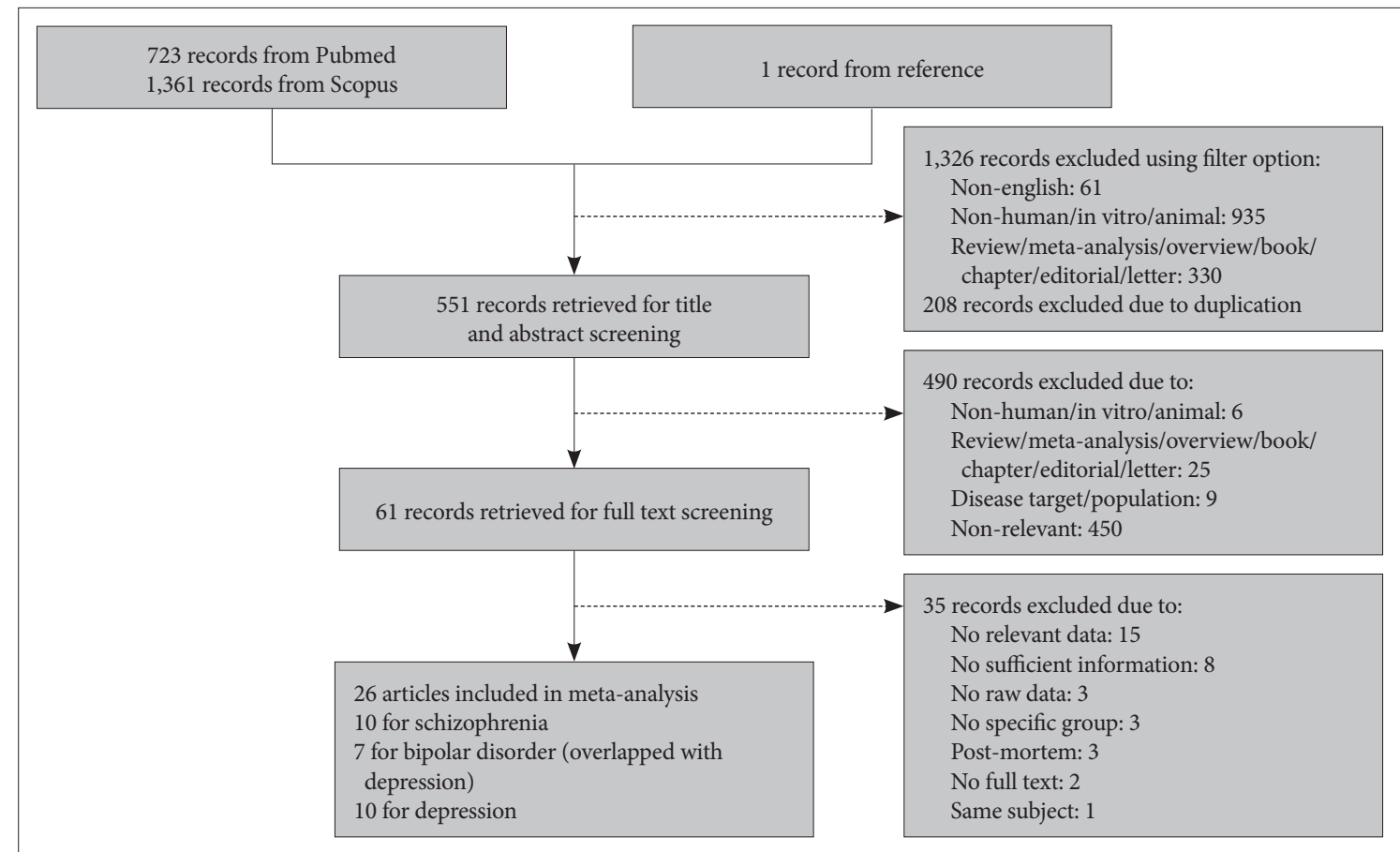

Figure 1. Flow diagram of study selection for meta-analysis of oxidative DNA damage.

respectively. Publication bias was checked using Egger's test ${ }^{21}$ and it was adjusted using trim-and-fill test ${ }^{22}$ if bias was present. Besides, subgroup analyses were performed in order to examine the 8-OHdG or 8-oxodG level according to specimens (lymphocyte, plasma/serum and urine), patient status (inpatients and outpatients), illness duration (less than 10 years and below, more than 10 years) and medication (no medication and on medication) in each illness, with minimum of two studies for each category. Subgroup analysis was also performed to examine ROS level according to medication history.

\section{RESULTS}

\section{Meta-analysis of oxidative DNA damage}

\section{Oxidative DNA damage in schizophrenia}

After screening, 10 studies with total of 1,026 subjects (546 patients and 480 controls) were included in the schizophrenic group. The 8-OHdG or 8-oxodG level was significantly higher (random-effects, Hedges's g=1.310, 95\% CI=0.491 to 2.130, $\mathrm{p}=0.002)$ in schizophrenic patients compared to healthy controls (Figure 3A) with the heterogeneity $\mathrm{I}^{2}$ of $97.7 \%[\mathrm{Q}=609.08$; $\mathrm{df}(\mathrm{Q})=14 ; \mathrm{p}<0.001]$. Publication bias tested using Egger's test was not significant $(\mathrm{p}=0.967)$.

\section{Oxidative DNA damage in bipolar disorder}

The literature search produced 7 studies with total subjects of 874, consisting of 513 patients and 361 controls. The oxida- tive DNA damage level was significantly increased (randomeffects, Hedges's g $=0.463,95 \% \mathrm{CI}=0.263$ to 0.622 , $\mathrm{p}<0.001$ ) in patients with bipolar disorder (Figure $3 \mathrm{~B}$ ). The heterogeneity $\mathrm{I}^{2}$ was $62.6 \%[\mathrm{Q}=32.08 ; \mathrm{df}(\mathrm{Q})=12 ; \mathrm{p}=0.001]$. In addition, there was no evidence of publication bias $(\mathrm{p}=0.771)$.

\section{Oxidative DNA damage in depression}

A total of 10 studies were included in present analysis, with 2,176 total subjects (671 patients and 1,505 controls). Mean effect size (Hedges' g) on oxidative DNA damage was - 0.410 (95\% $\mathrm{CI}=-0.495$ to -0.324$)$ in the fixed-effects model with no significant difference in the random-effects model (Figure 3C). Due to high heterogeneity $\left[\mathrm{I}^{2}=98.8 \%, \mathrm{Q}=895.45 ; \mathrm{df}(\mathrm{Q})=11 ; \mathrm{p}<0.001\right]$, the random-effects model was chosen. Publication bias was significant $(p=0.007)$. The funnel plot was asymmetric, and it was suggested that 5 studies were missing at the left side using Trim-and-Fill test (Figure 4). After adjustment, the imputed point estimate was -0.658 ( $95 \% \mathrm{CI}=-0.737$ to 0.579$)$ based on the fixed-effect model whereas the imputed point estimate was $-0.414(95 \% \mathrm{CI}=-1.088$ to 0.260 ) based on the random-effects model.

\section{Subgroup analyses}

The results of all subgroup analyses were summarised in Table 3.

\section{Biological specimens}

Oxidative DNA damage levels in lymphocyte, plasma/serum 


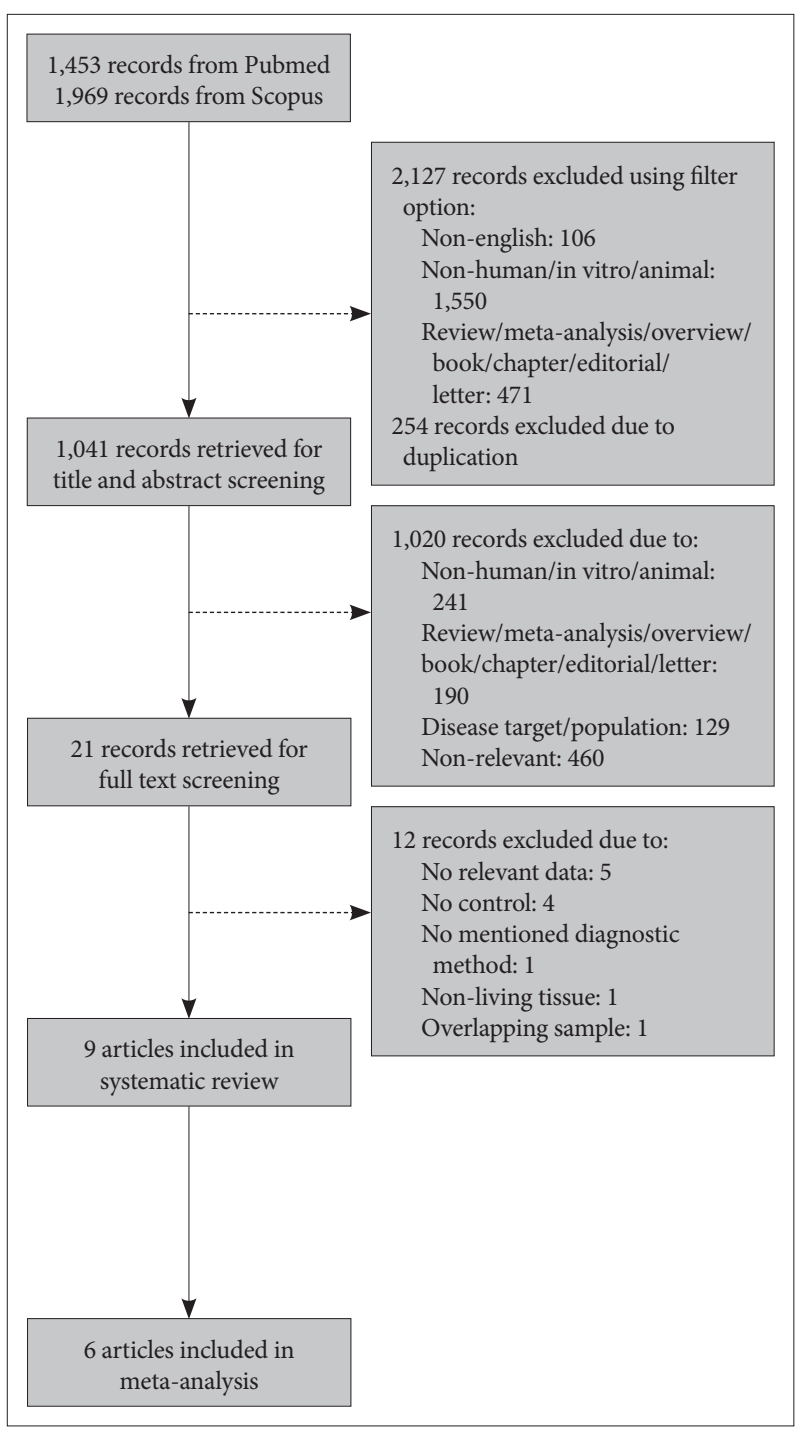

Figure 2. Flow diagram of study selection for systematic review and meta-analysis of reactive oxygen species (ROS).

and urine were analysed as there were minimum of two studies for each specimen. Due to expected heterogeneity, a randomeffects model was adopted for subgroup analyses. It can be seen that level of 8-OHdG or 8-oxodG was significantly increased in lymphocyte ( $\mathrm{p}=0.013$ ) of schizophrenic patients. Meanwhile in bipolar disorder, significant higher oxidative DNA damage level was observed in urine specimen only $(\mathrm{p}<0.001)$. In depressed patients, no significant changes of 8-OHdG or 8-oxodG level were detected in their plasma/serum or urine.

\section{Patient status}

Based on this subgroup analysis, significant oxidative DNA damage occurred only in the inpatients with schizophrenia and bipolar disorder ( $\mathrm{p}<0.001$ for both). There was no subgroup analysis for inpatients of depression as there was only one study.

\section{Illness duration}

Patients with schizophrenia $(\mathrm{p}=0.016)$ and bipolar disorder $(\mathrm{p}<0.001)$ for more than 10 years showed significantly larger effect size in oxidative DNA damage. No subgroup analysis was carried out for bipolar disorder patients with illness duration of 10 years and below as there was only one study.

\section{Medication history}

Schizophrenia patients, as well as bipolar disorder patients, who received medication showed significantly higher $(\mathrm{p}<0.001)$ oxidative DNA damage. No significant association was found in those without medication. In this subgroup analysis, only unmedicated depressed patients were included, as there was only one study that reported medicated patients.

\section{Systematic review and meta-analysis of ROS}

A total of 9 articles were included in present systematic review after screening. As 3 articles were not providing raw data, ${ }^{49,50,54}$ thus only 6 articles were included in meta-analysis. The study outcomes are shown in Table 2.

In schizophrenia, ROS was significantly higher in patients in comparison to healthy controls (fixed-effect, Hedges's $\mathrm{g}=0.712$, 95\% $\mathrm{CI}=0.269$ to $1.154, \mathrm{p}=0.002$ ) (Figure $5 \mathrm{~A})$. As heterogeneity was low, thus fixed-effect model was chosen $\left[\mathrm{I}^{2}=16.2 \%, \mathrm{Q}=\right.$ 1.193; $\mathrm{df}(\mathrm{Q})=1 ; \mathrm{p}=0.275$ ].

In depression, ROS was not significantly different between patients compared to healthy controls (random-effects, Hedges's $\mathrm{g}=0.306,95 \% \mathrm{CI}=-0.239$ to $0.851, \mathrm{p}=0.271$ ) (Figure $5 \mathrm{~B}$ ). The heterogeneity $\mathrm{I}^{2}$ was $87.2 \%[\mathrm{Q}=54.527 ; \mathrm{df}(\mathrm{Q})=7 ; \mathrm{p}<0.001]$. Publication bias tested using Egger's test was not significant ( $\mathrm{p}=0.751)$.

As schizophrenia group was only comprised of unmedicated patients, thus subgroup analysis based on medication history was only conducted in depression group (Table 4). However, no significant difference was observed in both medicated and unmedicated depressive patients.

\section{DISCUSSION}

The present meta-analysis found enhanced oxidative DNA damage indicated by 8-OHdG or 8-oxodG level in both schizophrenia and bipolar disorder patients. Our results were in agreement with the findings of previous meta-analyses on oxidative stress. ${ }^{8,16,58-60}$ To the best of our knowledge, this is the first metaanalysis study of the association between 8-OHdG or 8-oxodG level with schizophrenia. Redox imbalances, oxidative stress and impaired DNA damage repair, which may initiate cellular stress responses, have been observed in schizophrenia patients, ${ }^{30,61}$ especially those with a family history of schizophrenia. ${ }^{62}$ This high neuronal oxidative stress may cause poor prognosis by 


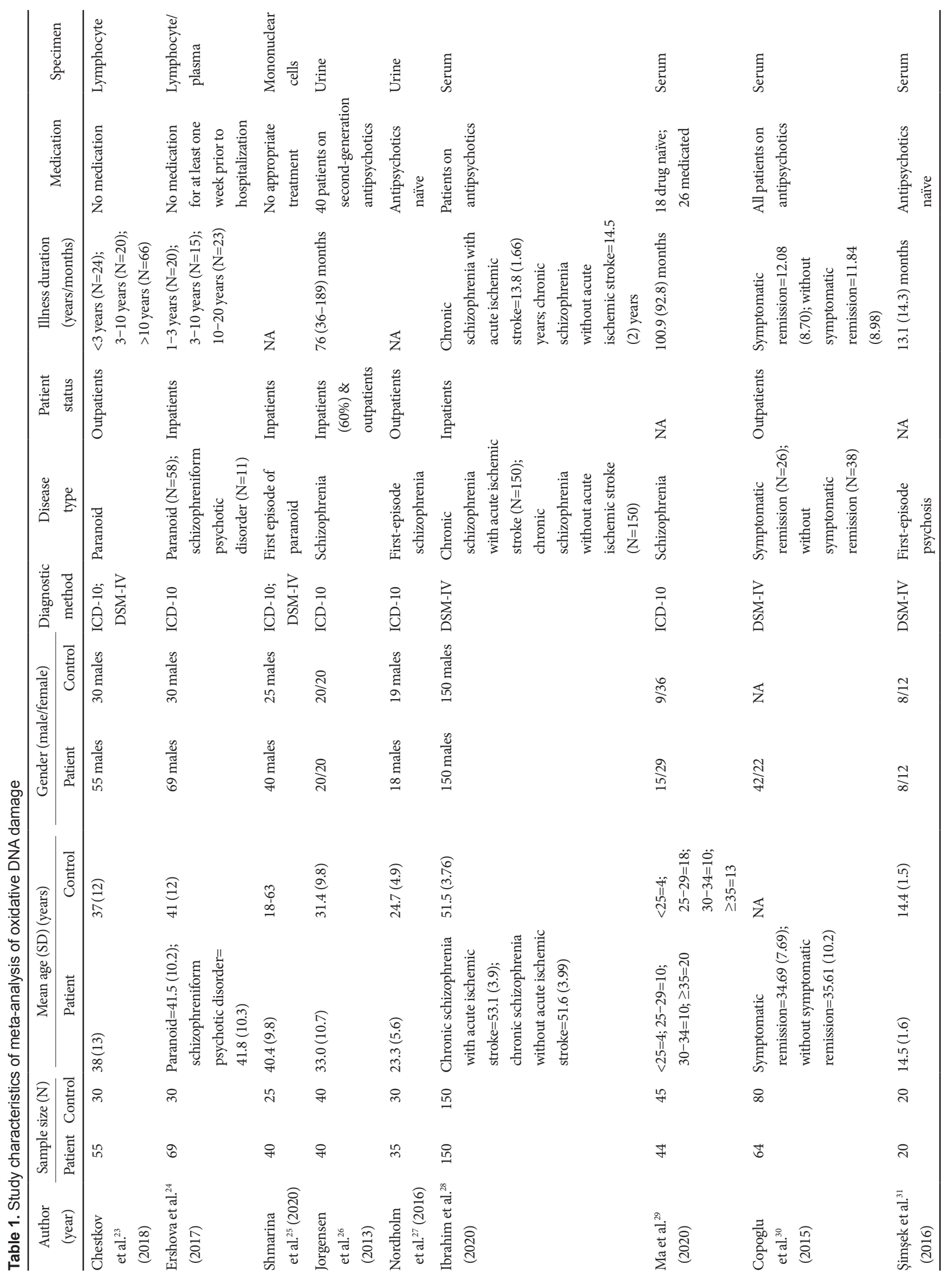




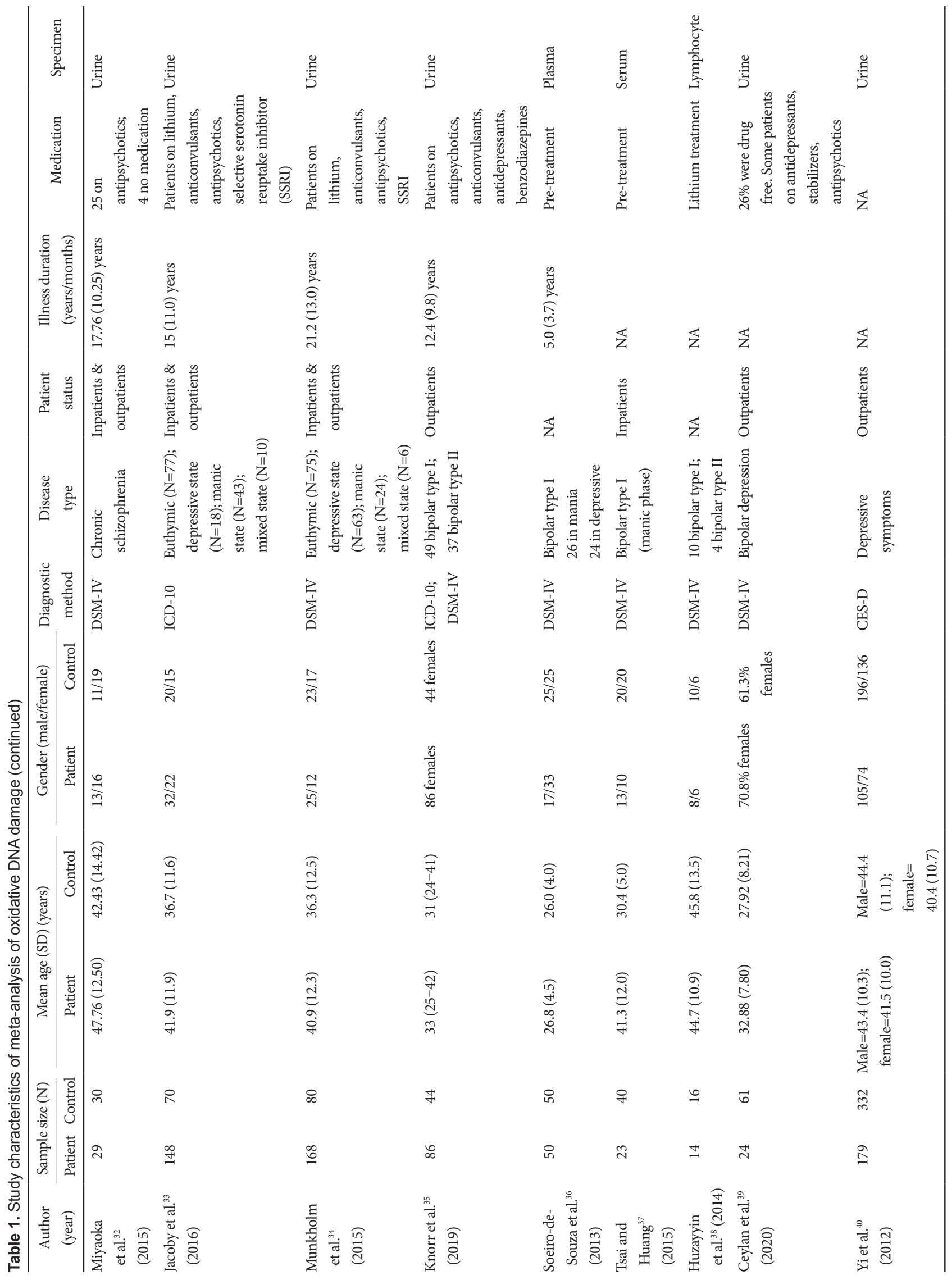


XX Goh et al.

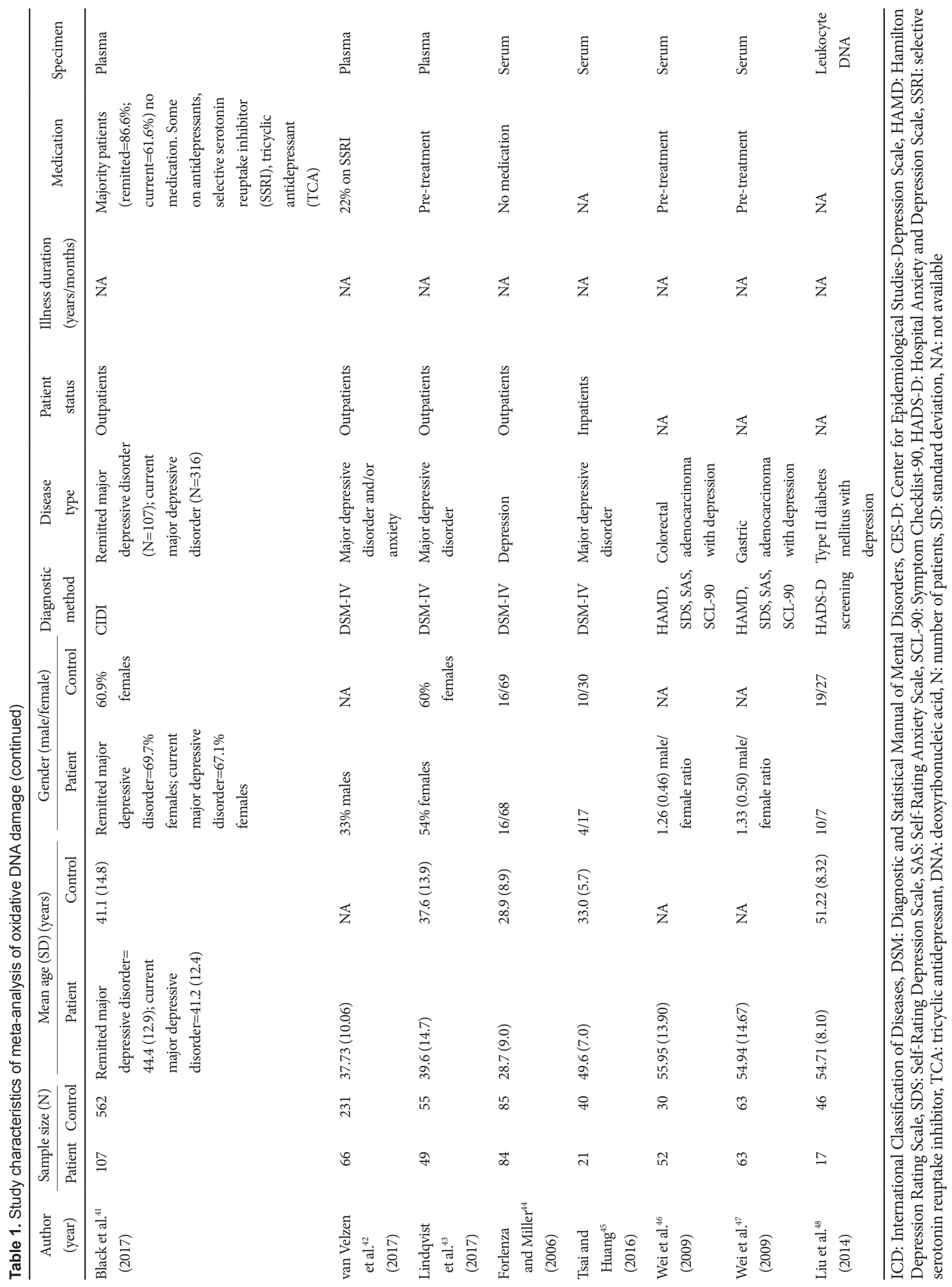




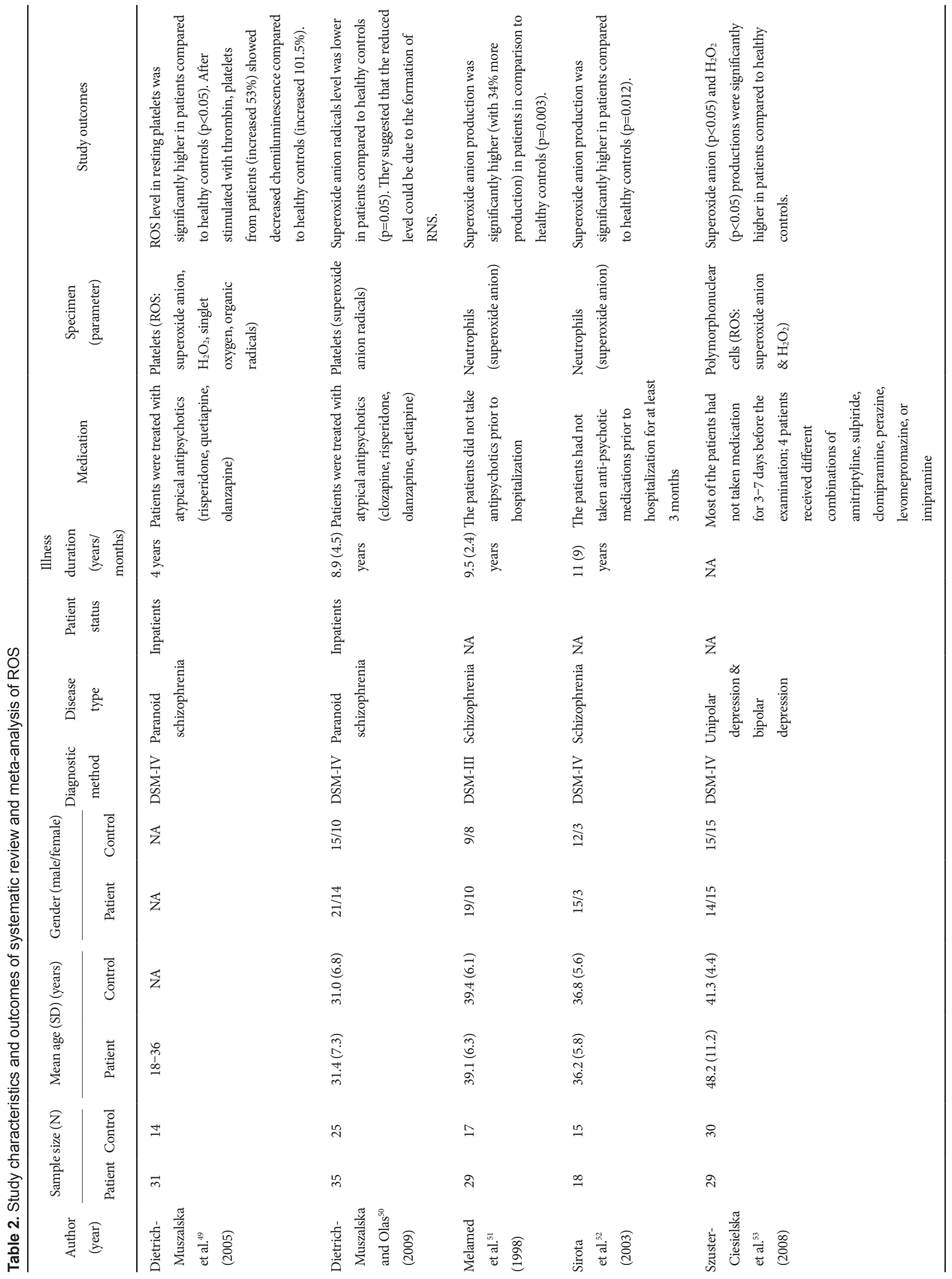


XX Goh et al.

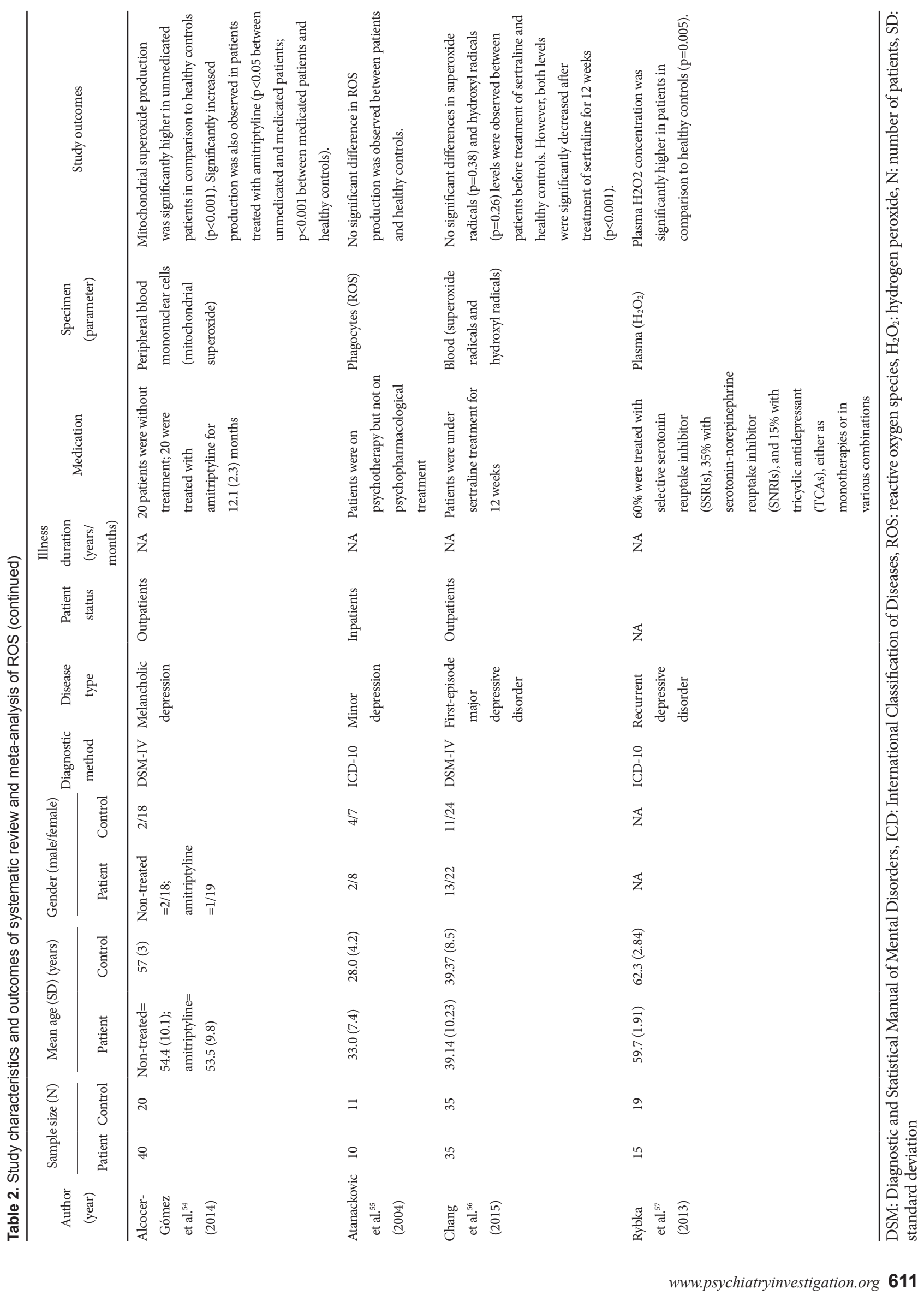




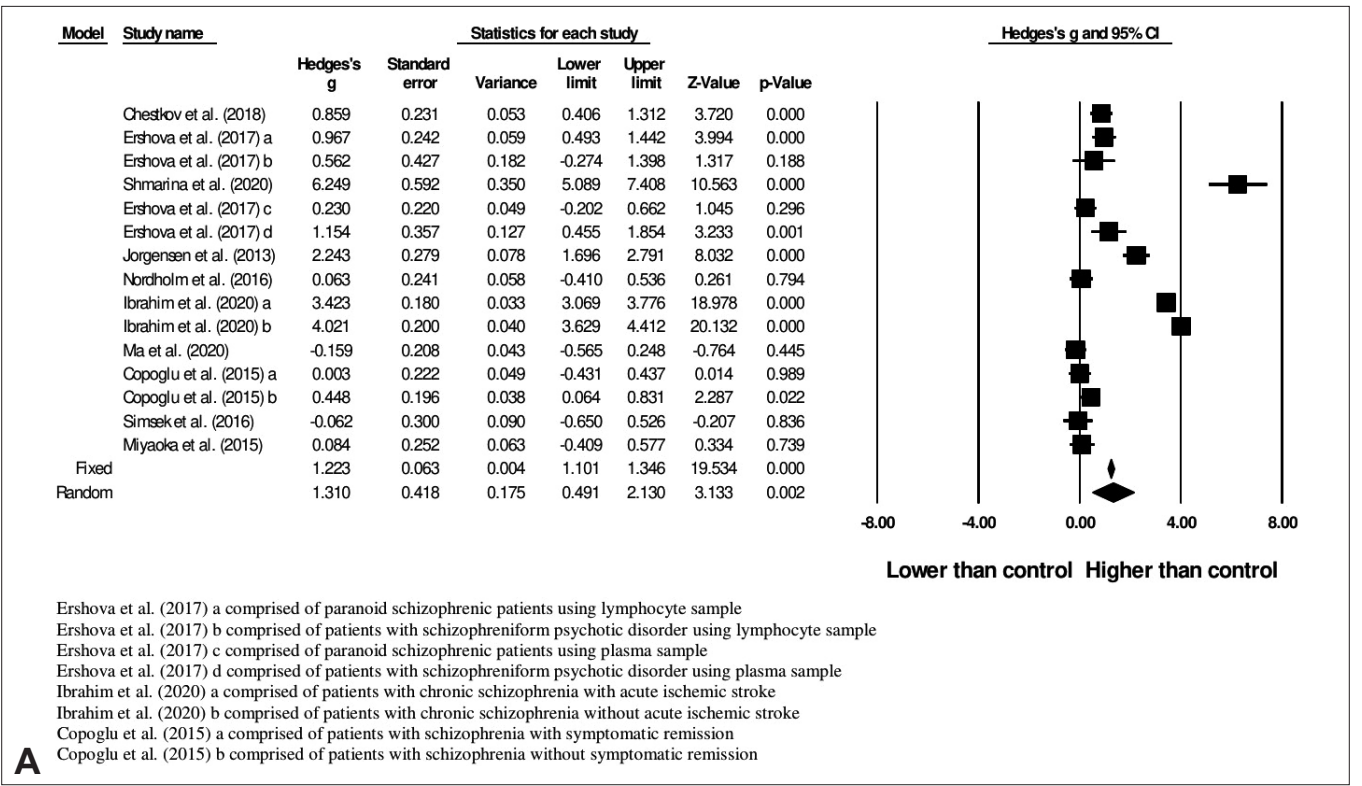

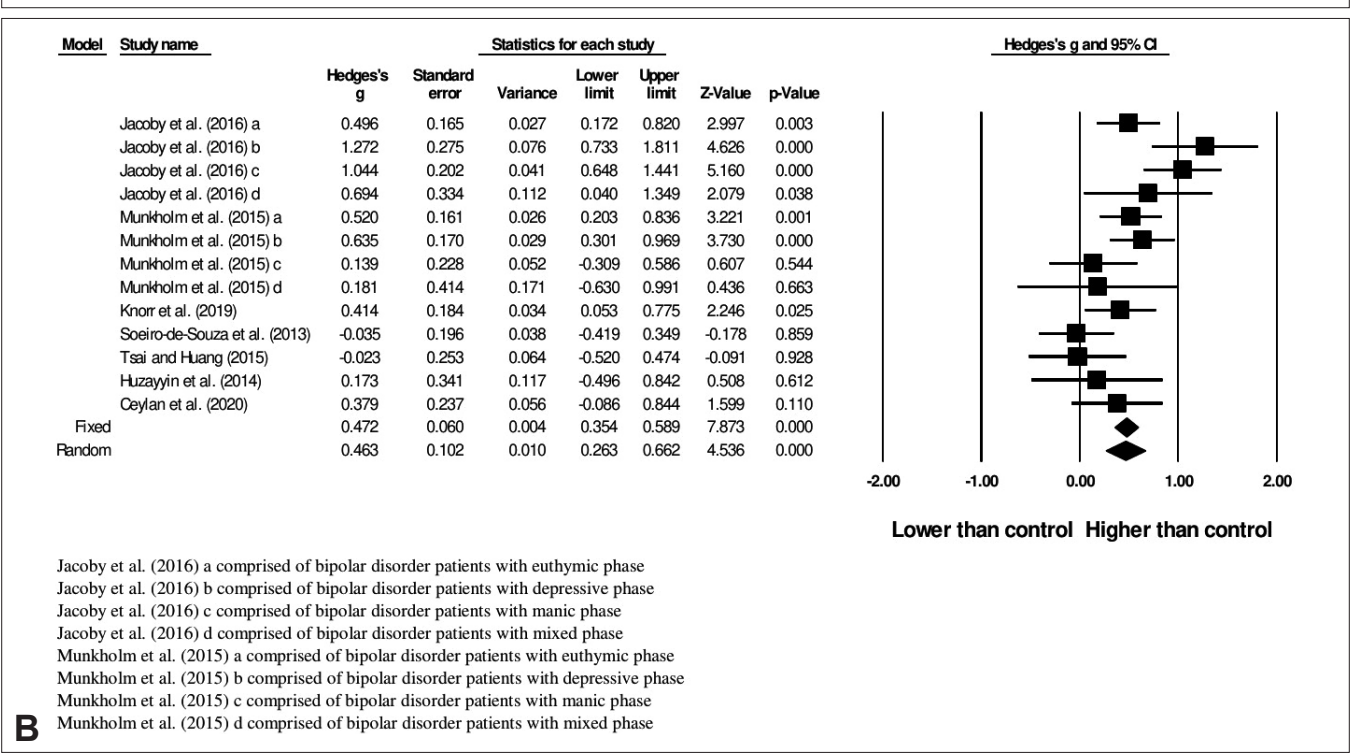

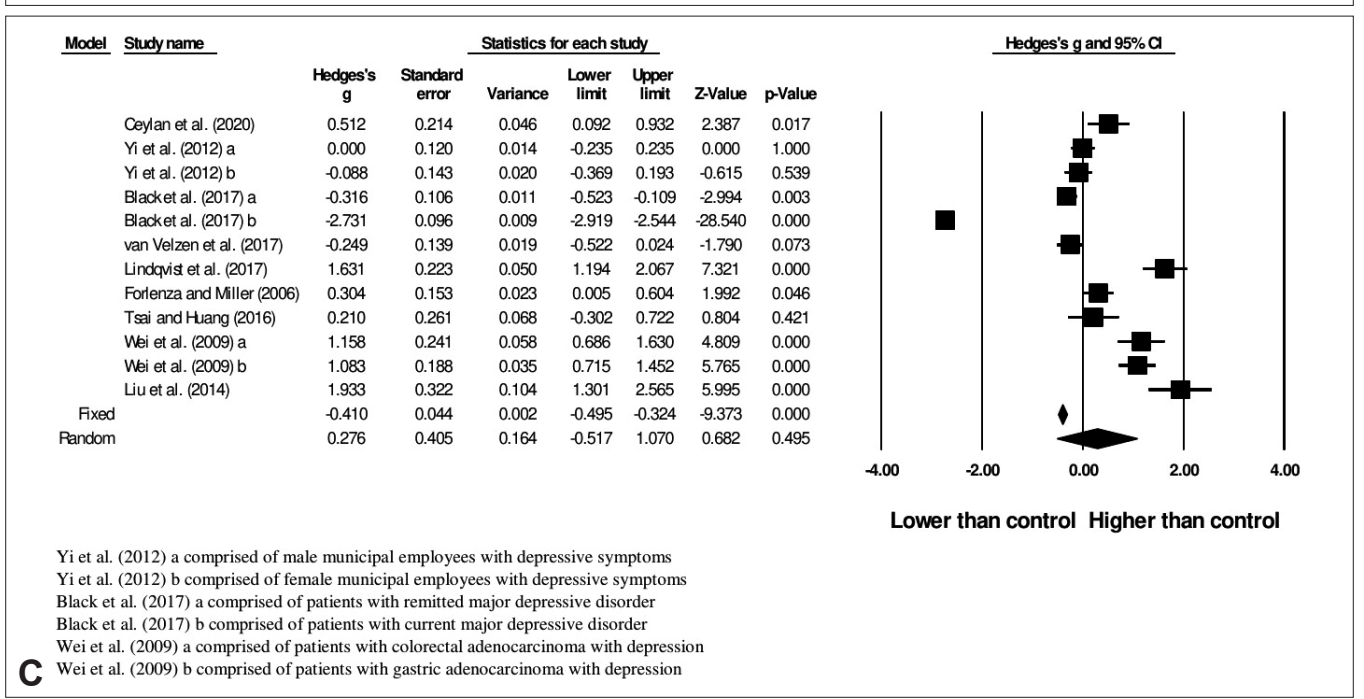

Figure 3. Meta-analysis of oxidative DNA damage (8-OHdG or 8-oxodG) in (A) schizophrenia, (B) bipolar disorder, and (C) depression. ${ }^{23-48}$ 


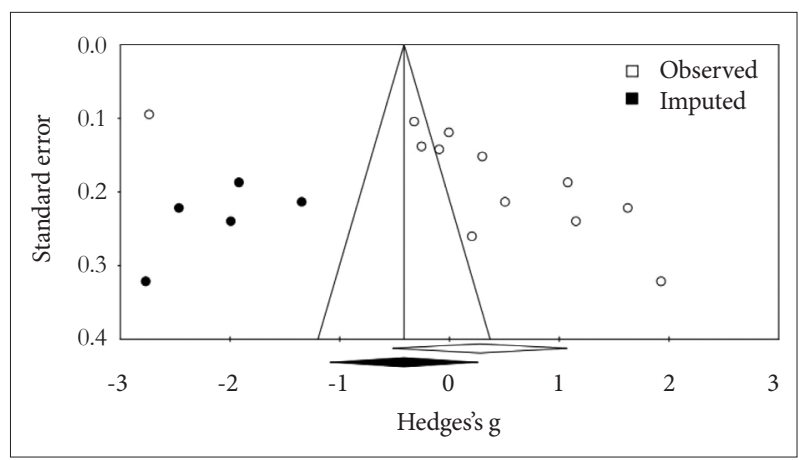

Figure 4. Funnel plot of oxidative DNA damage in depression (random-effects model).

disturbing metabolic activity, gene expression and cellular dysfunction. Besides, association between oxidative DNA damage and schizophrenia was also supported by previous post-mortem finding, that increased 8-OHdG was found in neuronal cytoplasm in hippocampus of elderly schizophrenic patients with poorer outcome. ${ }^{63}$

Bipolar disorder is the mental illness characterised by periodic episodes of mania (bipolar type I) or hypomania (bipolar type II) and depression. ${ }^{64}$ The symptom severity was found to be correlated with DNA damage. ${ }^{65}$ In a twin-case report, higher level of oxidative stress markers which may lead to lipid and protein oxidation with consequence of increased DNA damage was observed. ${ }^{66}$ Increased DNA damage was also found in twins as a trait because the lesion remained higher in comparison to healthy controls even after treatment of mood stabilization. Previous meta-analysis ${ }^{16}$ had first reported a larger effect size of DNA and RNA damage than our current study, due to their inclusion of both peripheral blood samples and post-mortem brain samples as well as measurements other than 8-OHdG or 8-oxodG. Post-mortem studies also demonstrated the involvement of DNA damage in bipolar disorder, particularly DNA fragmentation in anterior cingulate corte ${ }^{67}$ as well as in frontal cortex, pons, medulla, and thalamus ${ }^{68}$ From our result, it can be seen that the effect size of bipolar disorder was smaller than that of schizophrenia. This could be due to the occurrence of peripheral oxidative imbalance in the active phases of bipolar disorder only. ${ }^{69}$

It has been hypothesized that stressful life events leading to oxidative stress that involved in the pathophysiology of depression. ${ }^{70,71}$ Previous meta-analyses found that increased oxidative stress and decreased antioxidant level were associated with greater depressive symptoms. ${ }^{17,72,73}$ As we discussed before, high oxidative stress level is associating with oxidative DNA damage. However, no association between oxidative DNA damage with depression was found in present study according to random-effects model. It contrasted with the findings of previous meta-analysis study. ${ }^{74}$ This may be due to the different inclusion criteria used. In previous study, bipolar disorder, major depres-

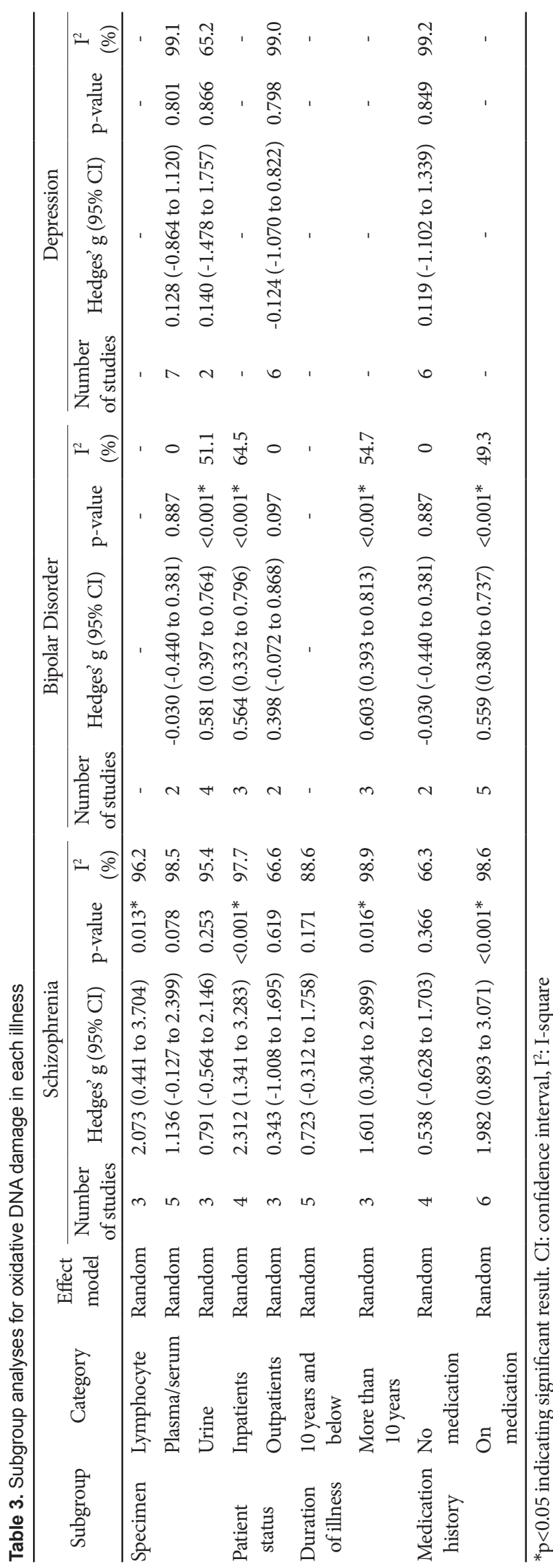

www.psychiatryinvestigation.org 613 


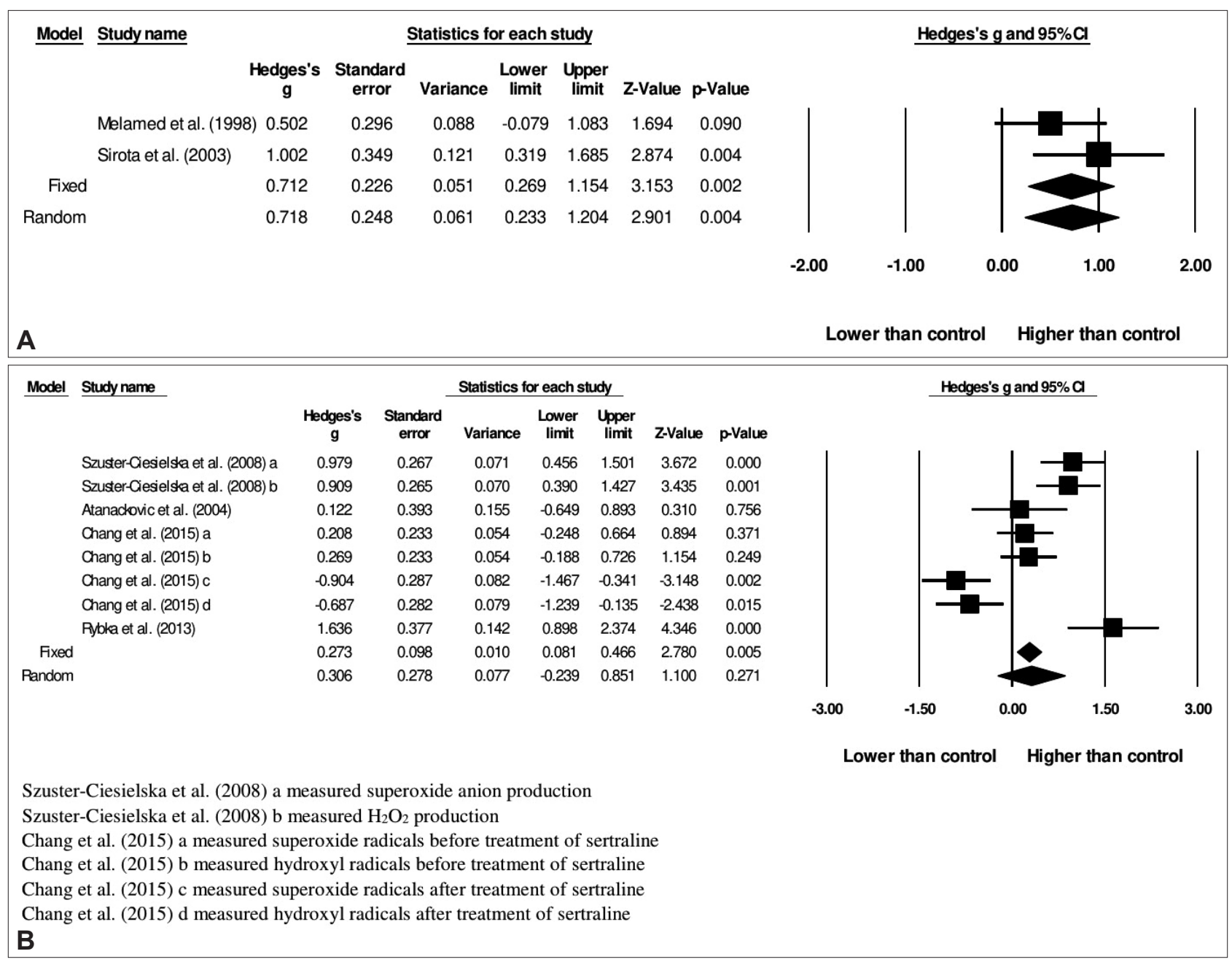

Figure 5. Meta-analysis of reactive oxygen species in (A) schizophrenia and (B) depression. ${ }^{49-57}$

Table 4. Subgroup analyses for reactive oxygen species in depression

\begin{tabular}{|c|c|c|c|c|c|c|}
\hline \multirow{2}{*}{ Subgroup } & \multirow{2}{*}{ Category } & \multirow{2}{*}{ Effect model } & \multicolumn{4}{|c|}{ Depression } \\
\hline & & & Number of studies & Hedges' g $(95 \%$ CI $)$ & $\mathrm{p}$-value & $\mathrm{I}^{2}(\%)$ \\
\hline \multirow[t]{2}{*}{ Medication history } & No medication & Random & 3 & $0.504(-0.143$ to 1.152$)$ & 0.127 & 56.0 \\
\hline & On medication & Random & 2 & $-0.040(-0.892$ to 0.812$)$ & 0.926 & 93.9 \\
\hline
\end{tabular}

CI: confidence interval, $\mathrm{I}^{2}$ : I-square

sive disorder and depression were classified as the same category, whereas we excluded bipolar disorder in the present analysis. Among the patients with major depressive disorder, the antidepressant users contrarily showed lower oxidative DNA damage. However, the precise roles of antidepressants in antiinflammation and antioxidative action are not fully understood. ${ }^{41}$

Due to the presence of heterogeneity and the wide distribution of data in forest plot, results obtained with random-effects model were preferred. High heterogeneity found in the present analysis may be due to several reasons such as clinical differences and single study designs. ${ }^{75}$ The different effect sizes found in subgroup analyses may also indicate the heterogeneity. On the other hand, since publication bias was not significant in the analyses of schizophrenia and bipolar disorder, thus it was not the reason causing high heterogeneity. However, significant publication bias may contribute certain extents to high heterogeneity in the analysis of depression. This publication bias may be due to the design of single studies, submission of results by researchers, rejection of negative studies by journals, source funding of studies and design of reviews or meta-analyses. ${ }^{76}$ The adjustment using Trim-and-Fill test showed that studies were missing at the left side of funnel plot. Thus, this significant publication bias might increase awareness in future to publish any results especially negative results (no effect or opposite ef- 
fects) which are failed to prove their hypotheses. ${ }^{77}$

Subgroup analyses were performed to determine the oxidative DNA damage in different biological specimens, patient status, illness duration and medication history for each mental illness. We found significant oxidative DNA damage in lymphocyte of schizophrenia patients and in urine of bipolar disorder patients. It may reflect the possibility of different mechanisms of oxidative DNA damage in each mental illness. As the major product of oxidative DNA damage, 8-OHdG or 8-oxodG will be released into bloodstream after being repaired and then be excreted by kidneys into urine. Hence, the plasma level of these deoxyguanosines may indicate how much oxidative stress has been exposed. It may represent the balance between DNA repair and clearance into urine within a period of time. However, some claimed that non-invasive urinary 8-oxodG originated from DNA of various tissues is better alternative in reflecting general oxidative stress as it is not dependent on changes of DNA repair and plasma clearance. ${ }^{78,79}$ On the other hand, peripheral lymphocytes are also being suggested in reflecting overall oxidative stress status of a whole organism because of their circulation in the body. ${ }^{80}$ Since many are questioning about the most favourable body samples to be selected in determining the level of deoxyguanosines, ${ }^{81}$ our findings may help future studies in choosing specific samples for each mental illness.

In this study, only inpatients of schizophrenia and bipolar disorder had significant oxidative DNA damage whereas no significant association was found in depression. The higher oxidative DNA damage among inpatients was accordance with the previous meta-analysis ${ }^{59}$ that chronic schizophrenia inpatients had lower antioxidants and higher oxidants whereas higher concentration of antioxidants was found in the stable medicated outpatients even though their lipid peroxidation was high. It was also suggested that longer illness duration might have cumulative effect in oxidative stress. ${ }^{82-84}$ Our subgroup analyses also showed that higher oxidative DNA damage was significantly evident in both schizophrenic and bipolar disorder patients with illness duration of more than 10 years. Interestingly, medicated schizophrenic and bipolar disorder patients showed more oxidative DNA damage. This is evidenced by the role of clozapine in increasing oxidative stress and DNA damage due to long-term use of high doses, accompanied with reduced glutathione (GSH) level and glutathione peroxidase (GSH-Px) activity that function as ROS scavengers. ${ }^{85}$ In addition, N-methyl-D-aspartate receptor (NMDAR) hypofunction may be inversely associated with oxidative stress in pathophysiology of schizophrenia. To enhance NMDAR efficacy, the inhibition of D-amino acid oxidase (DAAO) activity was suggested. ${ }^{86}$ It is known that the metabolism of D-amino acids by DAAO generates hydrogen peroxide which may result in oxidative damage. ${ }^{87}$ The application of sodium benzoate as DAAO inhibitor in clozapine-resistant schizophrenia increased catalase activity in decomposing hydrogen peroxide. ${ }^{88}$ Among antipsychotic medications, only blonanserin and risperidone owned stronger DAAO inhibitory effects based on in vitro study. ${ }^{89}$ Besides, animal study also demonstrated that increased oxidative damage in rat brain was induced by haloperidol and clozapine but not by olanzapine and aripiprazole. ${ }^{90}$ Antidepressant hydrazines such as isocarboxazid and phenelzine were also found to have a role in inactivating DNA when they react with oxygen and produce hydrogen peroxide. ${ }^{91}$ Therefore, it can be assumed that the positive association between oxidative DNA damage and medication was correlated with patient status and illness duration. This could be due to the higher usage of antipsychotics in inpatients compared to outpatients. ${ }^{92}$ Patients with longer illness duration were also assumed in taking more medications. No significant result was observed in depression as most of the patients were not hospitalized and not on medication.

As discussed, oxidative DNA damage is the consequence of oxidative stress that involves excessive ROS or RNS in impaired antioxidant mechanism. ${ }^{93}$ To the best of our knowledge, there was no systematic review or meta-analysis done on ROS in schizophrenia, bipolar disorder and depression yet. The present study revealed that higher ROS level was found in particularly unmedicated schizophrenic patients. However, studies ${ }^{49,50}$ also suggested the involvement of higher RNS level in schizophrenic patients treated with atypical antipsychotics. This was consistent with previous meta-analysis ${ }^{8}$ which found increased nitric oxide (NO) which is one of the RNS in medicated schizophrenic patients. Hence, these excess ROS/RNS levels may be correlated with increased oxidative DNA damage in schizophrenia found in present meta-analysis. On the other hand, direct measurement of ROS has been less studied compared with $\mathrm{NO}^{16}$ in patients with bipolar disorder. Meanwhile the current meta-analysis revealed that in depression, the non-significant differences in ROS level and oxidative DNA damage might be contributed by medication. Previous meta-analysis ${ }^{17}$ also reported that there was no significant difference in NO level between depressed patients and healthy controls. Therefore, we can postulate that different types of antidepressant may affect oxidative stress level, for instance amitriptyline increased ROS production, ${ }^{54}$ and sertraline decreased levels of superoxide radicals and hydroxyl radicals. ${ }^{56}$ This could be also supported by in vitro study which found tricyclic antidepressants (TCAs) and selective serotonin reuptake inhibitor (SSRIs) induced oxidative stress by increasing production of ROS and reducing glutathione level. ${ }^{94}$

Our present study has several limitations. First, some studies were excluded in present analysis as the information was insufficient or raw data were not provided. Thus, there might be certain influences on the overall result. Second, the associ- 
ation between oxidative DNA damage and other risk factors such as age ${ }^{95}$ or smoking status ${ }^{96}$ which have been found to have positive correlation with the damage was not analysed. We cannot rule out the possible effects of external factors such as diet or lifestyle on oxidative DNA damage to determine whether the damage is formed as the consequence of the illness. Besides, we were unable to evaluate the effect of specific antipsychotics drug as the subjects in studies were treated with variety of treatment. Furthermore, as there was insufficient number of studies, we were unable to conduct analysis of ROS level in bipolar disorder.

In conclusion, the present meta-analysis revealed that schizophrenia with the largest effect size and bipolar disorder were associated with increased oxidative DNA damage whereas no association between oxidative DNA damage and depression was observed. Subgroup analyses of oxidative DNA damage level in different biological specimens may indicate different mechanisms of lesion occurrence in different mental illness and may help future studies in choosing specific specimen for a particular mental illness. Other factors such as patient status, illness duration and medication history that may contribute certain effects on oxidative DNA damage need further investigation. The present study also revealed the relationship between high ROS level and schizophrenia but not in depression. More association studies between direct measurement ROS and oxidative DNA damage can be conducted in future to further confirm that 8-OHdG or 8-oxodG may have the potential to be used as biomarker of oxidative DNA damage and oxidative stress in mental illness, as well as to help in understanding the underlying pathophysiology of mental illnesses.

\section{Acknowledgments}

None.

\section{Conflicts of Interest}

The authors have no potential conflicts of interest to disclose.

\section{Author Contributions}

Conceptualization: all authors. Data curation: Xue Xin Goh. Formal analysis: Xue Xin Goh. Funding acquisition: Shiau Foon Tee. Investigation: all authors. Methodology: Xue Xin Goh. Project administration: Pek Yee Tang, Shiau Foon Tee. Resources: Pek Yee Tang, Shiau Foon Tee. Supervision: Pek Yee Tang, Shiau Foon Tee. Validation: Pek Yee Tang, Shiau Foon Tee. Writing_original draft: Xue Xin Goh. Writing_review \& editing: Pek Yee Tang, Shiau Foon Tee.

\section{ORCID iDs}

$\begin{array}{ll}\text { Xue Xin Goh } & \text { https://orcid.org/0000-0002-9481-3971 } \\ \text { Pek Yee Tang } & \text { https://orcid.org/0000-0001-5155-655X } \\ \text { Shiau Foon Tee } & \text { https://orcid.org/0000-0002-5089-1548 }\end{array}$

\section{REFERENCES}

1. GBD 2017 Disease and Injury Incidence and Prevalence Collaborators. Global, regional, and national incidence, prevalence, and years lived with disability for 354 Diseases and Injuries for 195 countries and territories, 1990-2017: a systematic analysis for the Global Burden of Disease Study 2017. Lancet 2018;392:1789-1858.

2. Rehm J, Shield KD. Global burden of disease and the impact of mental and addictive disorders. Curr Psychiatry Rep 2019;21:10.

3. Whiteford HA, Ferrari AJ, Degenhardt L, Feigin V, Vos T. Global Burden of Mental, Neurological, and Substance Use Disorders: An Analysis from the Global Burden of Disease Study 2010 (3rd Ed). In: Patel V, Chisholm D, Dua T, Laxminarayan R, Medina-Mora ME, editors. Mental, Neurological, and Substance Use Disorders: Disease Control Priorities. Washington, DC: The International Bank for Reconstruction and Development/The World Bank; 2016.

4. Halliwell B. Oxidative stress and neurodegeneration: where are we now? J Neurochem 2006;97:1634-1658.

5. Ng F, Berk M, Dean O, Bush AI. Oxidative stress in psychiatric disorders: Evidence base and therapeutic implications. Int J Neuropsychopharmacol 2008;11:851-876.

6. Smaga I, Niedzielska E, Gawlik M, Moniczewski A, Krzek J, Przegaliński $\mathrm{E}$, et al. Oxidative stress as an etiological factor and a potential treatment target of psychiatric disorders. Part 2. Depression, anxiety, schizophrenia and autism. Pharmacol Rep 2015;67:569-580.

7. Bulbul F, Virit O, Alpak G, Unal A, Bulut M, Kaya MC, et al. Are oxidative stress markers useful to distinguish schizoaffective disorder from schizophrenia and bipolar disorder? Acta Neuropsychiatr 2014;26: 120-124.

8. Zhang M, Zhao ZM, He L, Wan CL. A meta-analysis of oxidative stress markers in schizophrenia. Sci China Life Sci 2010;53:112-124.

9. Katerji M, Filippova M, Duerksen-Hughes P. Approaches and methods to measure oxidative stress in clinical samples: research applications in the cancer field. Oxid Med Cell Longev 2019;2019:1279250.

10. Hickerson RP, Prat F, Muller JG, Foote CS, Burrows CJ. Sequence and stacking dependence of 8-oxoguanine oxidation: comparison of oneelectron vs singlet oxygen mechanisms. J Am Chem Soc 1999;121:94239428.

11. Raza MU, Tufan T, Wang Y, Hill C, Zhu MY. DNA damage in major psychiatric diseases. Neurotox Res 2016;30:251-267.

12. Valavanidis A, Vlachogianni T, Fiotakis C. 8-Hydroxy-2'-deoxyguanosine (8-OHdG): a critical biomarker of oxidative stress and carcinogenesis. J Environ Sci Health C Environ Carcinog Ecotoxicol Rev 2009;27: 120-139.

13. Ock CY, Kim EH, Choi DJ, Lee HJ, Hahm KB, Chung MH. 8-hydroxydeoxyguanosine: Not mere biomarker for oxidative stress, but remedy for oxidative stress-implicated gastrointestinal diseases. World J Gastroenterol 2012;18:302-308.

14. Korkmaz KS, Butuner BD, Roggenbuck D. Detection of $8-\mathrm{OHdG}$ as a diagnostic biomarker. J Lab Precis Med 2018;3:95.

15. Salim S. Oxidative stress and psychological disorders. Curr Neuropharmacol 2014;12:140-147.

16. Brown NC, Andreazza AC, Young LT. An updated meta-analysis of oxidative stress markers in bipolar disorder. Psychiatry Res 2014;218: 61-68.

17. Liu T, Zhong S, Liao X, Chen J, He T, Lai S, et al. A meta-analysis of oxidative stress markers in depression. PLoS One 2015;10:e0138904.

18. Christensen MR, Poulsen HE, Henriksen T, Weimann A, Ellervik C, Lynnerup N, et al. Elevated levels of 8-oxoGuo and 8-oxodG in individuals with severe mental illness - An autopsy-based study. Free Radic Biol Med 2018;126:372-378.

19. Huedo-Medina TB, Sánchez-Meca J, Marín-Martínez F, Botella J. Assessing heterogeneity in meta-analysis: Q statistic or $\mathrm{I}^{2}$ Index? Psychol Methods 2006;11:193-206.

20. Lin E, Tong T, Chen Y, Wang Y. Fixed-effects model: the most convincing model for meta-analysis with few studies. Preprint arXiv:2002.04211.

21. Egger M, Smith GD, Schneider M, Minder C. Bias in meta-analysis detected by a simple, graphical test. BMJ 1997;315:629-634.

22. Duval S, Tweedie R. Trim and fill: A simple funnel-plot-based method 
of testing and adjusting for publication bias in meta-analysis. Biometrics 2000;56:455-463.

23. Chestkov IV, Jestkova EM, Ershova ES, Golimbet VG, Lezheiko TV, Kolesina NY, et al. ROS-induced DNA damage associates with abundance of mitochondrial DNA in white blood cells of the untreated schizophrenic patients. Oxid Med Cell Longev 2018;2018:8587475.

24. Ershova ES, Jestkova EM, Chestkov IV, Porokhovnik LN, Izevskaya VL, Kutsev SI, et al. Quantification of cell-free DNA in blood plasma and DNA damage degree in lymphocytes to evaluate dysregulation of apoptosis in schizophrenia patients. J Psychiatr Res 2017;87:15-22.

25. Shmarina GV, Orlova MD, Ershova ES, Jestkova EM, Martynov AV, Veiko NN, et al. NRF2 and HMOX1 gene expression against the background of systemic oxidative stress in patients with acute psychosis. Russ J Genet 2020;56:96-102.

26. Jorgensen A, Broedbaek K, Fink-Jensen A, Knorr U, Soendergaard MG, Henriksen T, et al. Increased systemic oxidatively generated DNA and RNA damage in schizophrenia. Psychiatry Res 2013;209:417-423.

27. Nordholm D, Poulsen HE, Hjorthøj C, Randers L, Nielsen MØ, Wulff $\mathrm{S}$, et al. Systemic oxidative DNA and RNA damage are not increased during early phases of psychosis: a case control study. Psychiatry Res 2016;241:201?206.

28. Ibrahim RR, Amer RA, Abozeid AA, Elsharaby RM, Shafik NM. Micro RNA 146a gene variant/TNF- $\alpha /$ IL-6/IL-1 $\beta$; a cross-link axis in between oxidative stress, endothelial dysfunction and neuro-inflammation in acute ischemic stroke and chronic schizophrenic patients. Arch Biochem 2020;679:108193.

29. Ma J, Yan L, Guo T, Yang S, Ni D, Liu Y, et al. A pilot study of biomarkers of oxidative stress in serum and schizophrenia. Psychiatry Res 2020; 284:112757.

30. Copoglu US, Virit O, Kokacya MH, Orkmez M, Bulbul F, Erbagci AB, et al. Increased oxidative stress and oxidative DNA damage in non-remission schizophrenia patients. Psychiatry Res 2015;229:200-205.

31. Şimşek Ş, Gençoğlan S, Yüksel T, Kaplan İ, Alaca R, Aktaş H. Oxidative stress and DNA damage in untreated first-episode psychosis in adolescents. Neuropsychobiology 2016;73:92-97.

32. Miyaoka T, Ieda M, Hashioka S, Wake R, Furuya M, Liaury K, et al. Analysis of oxidative stress expressed by urinary level of biopyrrins and 8-hydroxydeoxyguanosine in patients with chronic schizophrenia. Psychiatry Clin Neurosci 2015;69:693-698.

33. Jacoby AS, Vinberg M, Poulsen HE, Kessing LV, Munkholm K. Increased DNA and RNA damage by oxidation in patients with bipolar I disorder. Transl Psychiatry 2016;6:e867.

34. Munkholm K, Poulsen HE, Kessing LV, Vinberg M. Elevated levels of urinary markers of oxidatively generated DNA and RNA damage in bipolar disorder. Bipolar Disord 2015;17:257-268.

35. Knorr U, Simonsen AH, Roos P, Weimann A, Henriksen T, Christensen EM, et al. Cerebrospinal fluid oxidative stress metabolites in patients with bipolar disorder and healthy controls: a longitudinal case-control study. Transl Psychiatry 2019;9:325.

36. Soeiro-de-Souza MG, Andreazza AC, Carvalho AF, Machado-Vieira R, Young LT, Moreno RA. Number of manic episodes is associated with elevated DNA oxidation in bipolar I disorder. Int J Neuropsychopharmacol 2013;16:1505-1512.

37. Tsai MC, Huang TL. Thiobarbituric acid reactive substances (TBARS) is a state biomarker of oxidative stress in bipolar patients in a manic phase. J Affect Disord 2015;173:22-26.

38. Huzayyin AA, Andreazza AC, Turecki G, Cruceanu C, Rouleau GA, Alda $\mathrm{M}$, et al. Decreased global methylation in patients with bipolar disorder who respond to lithium. Int J Neuropsychopharmacol 2014; 17:561-569.

39. Ceylan D, Yilmaz S, Tuna G, Kant M, Er A, Ildız A, et al. Alterations in levels of 8-Oxo-2'-deoxyguanosine and 8-Oxoguanine DNA glycosylase 1 during a current episode and after remission in unipolar and bipolar depression. Psychoneuroendocrinology 2020;114:104600.

40. Yi S, Nanri A, Matsushita Y, Kasai H, Kawai K, Mizoue T. Depressive symptoms and oxidative DNA damage in Japanese municipal employees. Psychiatry Res 2012;200:318-322.

41. Black CN, Bot M, Scheffer PG, Penninx BWJH. Oxidative stress in major depressive and anxiety disorders, and the association with antidepressant use; results from a large adult cohort. Psychol Med 2017;47: 936-948.

42. van Velzen LS, Wijdeveld M, Black CN, van Tol MJ, van der Wee NJA, Veltman DJ, et al. Oxidative stress and brain morphology in individuals with depression, anxiety and healthy controls. Prog Neuropsychopharmacol Biol Psychiatry 2017;76:140-144.

43. Lindqvist D, Dhabhar FS, James SJ, Hough CM, Jain FA, Bersani FS, et al. Oxidative stress, inflammation and treatment response in major depression. Psychoneuroendocrinology 2017;76:197-205.

44. Forlenza MJ, Miller GE. Increased serum levels of 8-hydroxy-2'-deoxyguanosine in clinical depression. Psychosom Med 2006;68:1-7.

45. Tsai MC, Huang TL. Increased activities of both superoxide dismutase and catalase were indicators of acute depressive episodes in patients with major depressive disorder. Psychiatry Res 2016;235:38-42.

46. Wei Y, Zhou F, He D, Bai J, Hui L, Wang X, et al. The level of oxidative stress and the expression of genes involved in DNA-damage signaling pathways in depressive patients with colorectal carcinoma. J Psychosom Res 2009;66:259-266.

47. Wei YC, Zhou FL, He DL, Bai JR, Ding H, Wang XY, et al. Oxidative stress in depressive patients with gastric adenocarcinoma. Int J Neuropsychopharmacol 2009;12:1089-1096.

48. Liu Z, Zhang J, Yan J, Wang Y, Li Y. Leucocyte telomere shortening in relation to newly diagnosed type 2 diabetic patients with depression. Oxid Med Cell Longev 2014;2014:673959.

49. Dietrich-Muszalska A, Olas B, Rabe-Jablonska J. Oxidative stress in blood platelets from schizophrenic patients. Platelets 2005;16:386-391.

50. Dietrich-Muszalska A, Olas B. Modifications of blood platelet proteins of patients with schizophrenia. Platelets 2009;20:90-96.

51. Melamed Y, Sirota P, Dicker DR, Fishman P. Superoxide anion production by neutrophils derived from peripheral blood of schizophrenic patients. Psychiatry Res 1998;77:29-34.

52. Sirota P, Gavrieli R, Wolach B. Overproduction of neutrophil radical oxygen species correlates with negative symptoms in schizophrenic patients: parallel studies on neutrophil chemotaxis, superoxide production and bactericidal activity. Psychiatry Res 2003;121:123-132.

53. Szuster-Ciesielska A, Słotwińska M, Stachura A, MarmurowskaMichałowska H, Dubas-Ślemp H, Bojarska-Junak A, et al. Accelerated apoptosis of blood leukocytes and oxidative stress in blood of patients with major depression. Prog Neuropsychopharmacol Biol Psychiatry 2008;32:686-694.

54. Alcocer-Gómez E, de Miguel M, Casas-Barquero N, Núñez-Vasco J, Sánchez-Alcazar JA, Fernández-Rodríguez A, et al. NLRP3 inflammasome is activated in mononuclear blood cells from patients with major depressive disorder. Brain Behav Immun 2014;36:111-117.

55. Atanackovic D, Kröger H, Serke S, Deter HC. Immune parameters in patients with anxiety or depression during psychotherapy. J Affect Disord 2004;81:201-209.

56. Chang CC, Lee CT, Lan TH, Ju PC, Hsieh YH, Lai TJ. Effects of antidepressant treatment on total antioxidant capacity and free radical levels in patients with major depressive disorder. Psychiatry Res 2015;230: 575-580.

57. Rybka J, Kędziora-Kornatowska K, Banaś-Leżańska P, Majsterek I, Carvalho LA, Cattaneo A, et al. Interplay between the pro-oxidant and antioxidant systems and proinflammatory cytokine levels, in relation to iron metabolism and the erythron in depression. Free Radic Biol Med 2013;63:187-194.

58. Andreazza AC, Kauer-Sant'Anna M, Frey BN, Bond DJ, Kapczinski F, Young LT, et al. Oxidative stress markers in bipolar disorder: a metaanalysis. J Affect Disord 2008;111:135-144.

59. Flatow J, Buckley P, Miller BJ. Meta-analysis of oxidative stress in schizophrenia. Biol Psychiatry 2013;74:400-409. 
60. Rowland T, Perry BI, Upthegrove R, Barnes N, Chatterjee J, Gallacher $D$, et al. Neurotrophins, cytokines, oxidative stress mediators and mood state in bipolar disorder: systematic review and meta-analyses. Br J Psychiatry 2018;213:514-525.

61. Markkanen E, Meyer U, Dianov GL. DNA damage and repair in schizophrenia and autism: implications for cancer comorbidity and beyond. Int J Mol Sci 2016;17:856.

62. Muraleedharan A, Menon V, Rajkumar RP, Chand P. Assessment of DNA damage and repair efficiency in drug naïve schizophrenia using comet assay. J Psychiatr Res 2015;68:47-53.

63. Nishioka N, Arnold SE. Evidence for oxidative DNA damage in the hippocampus of elderly patients with chronic schizophrenia. Am J Geriatr Psychiatry 2004;12:167-175.

64. Anderson IM, Haddad PM, Scott J. Bipolar disorder. BMJ 2012;345: e8508.

65. Andreazza AC, Frey BN, Erdtmann B, Salvador M, Rombaldi F, Santin A, et al. DNA damage in bipolar disorder. Psychiatry Res 2007;153:2732.

66. Frey BN, Andreazza AC, Kunz M, Gomes FA, Quevedo J, Salvador M, et al. Increased oxidative stress and DNA damage in bipolar disorder: a twin-case report. Prog Neuropsychopharmacol Biol Psychiatry 2007; 31:283-285.

67. Buttner N, Bhattacharyya S, Walsh J, Benes FM. DNA fragmentation is increased in non-GABAergic neurons in bipolar disorder but not in schizophrenia. Schizophr Res 2007;93:33-41.

68. Mustak MS, Hegde ML, Dinesh A, Britton GB, Berrocal R, Rao KS, et al. Evidence of altered DNA integrity in the brain regions of suicidal victims of bipolar depression. Indian J Psychol Med 2010;52:220-228.

69. Andreazza AC, Cassini C, Rosa AR, Leite MC, de Almeida LMV, Nardin P, et al. Serum S100B and antioxidant enzymes in bipolar patients. J Psychiatr Res 2007;41:523-529.

70. Kessler RC. The effects of stressful life events on depression. Annu Rev Psychol 1997;48:191-214.

71. Patki G, Solanki N, Atrooz F, Allam F, Salim S. Depression, anxietylike behavior and memory impairment are associated with increased oxidative stress and inflammation in a rat model of social stress. Brain Res 2013;1539:73-86.

72. Jiménez-Fernández S, Gurpegui M, Díaz-Atienza F, Pérez-Costillas L, Gerstenberg M, Correll CU. Oxidative stress and antioxidant parameters in patients with major depressive disorder compared to healthy controls before and after antidepressant treatment. J Clin Psychiatry 2015;76:1658-1667.

73. Palta P, Samuel LJ, Miller ER, Szanton SL. Depression and oxidative stress: Results from a meta-analysis of observational studies. Psychosom Med 2014;76:12-19.

74. Black CN, Bot M, Scheffer PG, Cuijpers P, Penninx BWJH. Is depression associated with increased oxidative stress? A systematic review and meta-analysis. Psychoneuroendocrinology 2015;51:164-175.

75. Fletcher J. What is heterogeneity and is it important? Br Med J 2007; 334:94-96.

76. Thornton A, Lee P. Publication bias in meta-analysis: its causes and consequences. J Clin Epidemiol 2000;53:207-216.

77. Mlinarić A, Horvat M, Smolčić VŠ. Dealing with the positive publication bias: why you should really publish your negative results. Biochem Med 2017;27:447-452.

78. Henriksen T, Hillestrøm PR, Poulsen HE, Weimann A. Automated method for the direct analysis of 8-oxo-guanosine and 8-oxo-2'-deoxyguano- sine in human urine using ultraperformance liquid chromatography and tandem mass spectrometry. Free Radic Biol Med 2009;47:629-635.

79. Poulsen HE, Nadal LL, Broedbaek K, Nielsen PE, Weimann A. Detection and interpretation of 8-oxodG and 8-oxoGua in urine, plasma and cerebrospinal fluid. Biochim Biophys Acta 2014;1840:801-808.

80. Collins AR, Oscoz AA, Brunborg G, Gaivão I, Giovannelli L, Kruszewski M, et al. The comet assay: topical issues. Mutagenesis 2008;23:143151.

81. Halliwell B. Why and how should we measure oxidative DNA damage in nutritional studies? How far have we come? Am J Clin Nutr 2000; 72:1082-1087.

82. Kapczinski F, Vieta E, Andreazza AC, Frey BN, Gomes FA, Tramontina J, et al. Allostatic load in bipolar disorder: implications for pathophysiology and treatment. Neurosci Biobehav Rev 2008;32:675-692.

83. Kapczinski F, Dias VV, Kauer-Sant'Anna M, Brietzke E, Vázquez GH, Vieta E, et al. The potential use of biomarkers as an adjunctive tool for staging bipolar disorder. Prog Neuropsychopharmacol Biol Psychiatry 2009;33:1366-1371.

84. Nguyen TT, Eyler LT, Jeste DV. Systemic biomarkers of accelerated aging in schizophrenia: a critical review and future directions. Schizophr Bull 2018;44:398-408.

85. Abdel-Wahab BA, Abdalla ME, El-khawanki MM. Does clozapine induce myocarditis, myocardial oxidative stress and DNA damage in rats? Egypt J Forensic Sci 2014;4:75-82.

86. Lin CH, Lane HY. Early identification and intervention of schizophrenia: insight from hypotheses of glutamate dysfunction and oxidative stress. Front Psychiatry 2019;10:93.

87. Williams RE, Lock EA. Sodium benzoate attenuates D-serine induced nephrotoxicity in the rat. Toxicology 2005;207:35-48.

88. Lin CH, Lin CH, Chang YC, Huang YJ, Chen PW, Yang HT, et al. Sodium benzoate, a $\mathrm{D}$-amino acid oxidase inhibitor, added to clozapine for the treatment of schizophrenia: a randomized, double-blind, placebo-controlled trial. Biol Psychiatry 2018;84:422-432.

89. Shishikura M, Hakariya H, Iwasa S, Yoshio T, Ichiba $\mathrm{H}$, Yorita $\mathrm{K}$, et al. Evaluation of human D-amino acid oxidase inhibition by anti-psychotic drugs in vitro. Biosci Trends 2014;8:149-154.

90. Martins MR, Petronilho FC, Gomes KM, Dal-Pizzol F, Streck EL, Quevedo J. Antipsychotic-induced oxidative stress in rat brain. Neurotox Res 2008;13:63-69.

91. Freese E, Sklarow S, Freese EB. DNA damage caused by antidepressant hydrazines and related drugs. Mutat Res 1968;5:343-348.

92. Alosaimi FD, Alhabbad A, Abalhassan MF, Fallata EO, Alzain NM, Alassiry MZ, et al. Patterns of psychotropic medication use in inpatient and outpatient psychiatric settings in Saudi Arabia. Neuropsychiatr Dis Treat 2016;12:897-907.

93. Smith JA, Park S, Krause JS, Banik NL. Oxidative stress, DNA damage, and the telomeric complex as therapeutic targets in acute neurodegeneration. Neurochem Int 2013;62:764-75.

94. Post A, Crochemore C, Uhr M, Holsboer F, Behl C. Differential induction of NF- $\mathrm{\kappa B}$ activity and neural cell death by antidepressants in vitro. Eur J Neurosci 2000;12:4331-4337.

95. Hamilton ML, Van Remmen H, Drake JA, Yang H, Guo ZM, Kewitt K, et al. Does oxidative damage to DNA increase with age? Proc Natl Acad Sci USA 2001;98:10469-10474.

96. Graille M, Wild P, Sauvain JJ, Hemmendinger M, Canu IG, Hopf NB. Urinary 8-OHdG as a biomarker for oxidative stress: a systematic literature review and meta-analysis. Int J Mol Sci 2020;21:3743. 